\title{
Proses Kebijakan di Daerah: Formulasi Peraturan Daerah Provinsi Riau tentang Pengelolaan Daerah Aliran Sungai
}

\author{
Reski Lestari ${ }^{1}$, Riant Nugroho ${ }^{2}$, Syed Agung Afandi ${ }^{3}$ \\ ${ }^{1}$ Siyasah Syar'iyyah (Hukum Tata Negara), Sekolah Tinggi Agama Islam Negeri (STAIN) Bengkalis \\ ${ }^{2}$ Magister IImu Pemerintahan, Universitas Jenderal Achmad Yani \\ ${ }^{3}$ Administrasi Negara, Universitas Islam Negeri Sultan Syarif Kasim Riau \\ Email: reskilestari93@gmail.com
}

\begin{abstract}
Abstrak
Penurunan kondisi Daerah Aliran Sungai (DAS) di Indonesia ditandai dengan peningkatan tanah longsor, erosi dan sedimentasi, banjir, dan kekeringan. Setiap DAS memiliki permasalahannya sendiri sehingga dalam pengelolaan DAS diperlukan aturan yang khusus mengatur permasalah di DAS tersebut. Pengelolaan DAS Provinsi Riau diperlukan peraturan atau payung hukum yang khusus mengatur tentang DAS Provinsi Riau yang sesuai dengan klarifikasi dari DAS tersebut. Dalam hal ini muncul Ranperda inisiatif komisi DPRD Provinsi Riau Komisi B dalam Pengelolaan DAS di Provinsi Riau. Artikel ini menggunakan pendekatan kualitatif dengan metode analisis deskriptif, pengumpulan data dilakukan dengan wawancara, obsrvasi dan dokumentasi. Hasil penelitian menunjukkan dalam perumusan kebijakan Peraturan Daerah Provinsi Riau tentang Pengelolaan DAS terdapat beberapa proses dan tahapan yaitu perumusan masalah (defining problem), agenda kebijakan, pemilihan alternatif kebijakan untuk memecahkan masalah, dan terakhir tahap penetapan kebijakan. Dari proses perumusan yang dilakukan, draf awal Ranperda dengan draf setelah rapat paripurna yang telah dilakukan tidak mengalami perubahan yang signifikan, perubahan hanya berkisar pada penambahan konsep dalam pengelolaan DAS yang diwujudkan dalam Ranperda.
\end{abstract}

Kata kunci: Daerah Aliran Sungai, formulasi kebijakan, peraturan daerah

\begin{abstract}
The decline in watershed conditions in Indonesia has been marked by an increase in landslides, erosion and sedimentation, flooding, and drought. Each watershed has its problems, so that in watershed management, special rules are needed to regulate problems on the watershed. The management of the watershed in Riau Province requires specific regulations governing the Riau Province watershed in accordance with the clarification of the watershed. In this case, an initiative draft of The Commission B of Riau's Legislative Council appeared in the management of watersheds in Riau Province. This article uses a qualitative approach with descriptive analysis methods, data collection is through interview, observation and documentation. The results showed that in the formulation of the Riau Province Regional Regulation on Watershed Management, there were several processes and stages, namely the formulation of problems, the policy agenda, the selection of alternative policies to solve problems, and finally the stage of determining the policy. From the formulation process that was carried out, the initial draft with the draft after the Plenary Meeting that had been carried out did not experience significant changes, the changes only revolved around adding concepts in watershed management which were embodied in the Regional Regulation Draft.
\end{abstract}

Keywords: watershed, policy formulation, regional regulations 


\section{PENDAHULUAN}

Daerah Aliran Sungai sering disingkat dengan (DAS) dapat diartikan sebagai satu kesatuan ekosistem hidrologi yang didalamnya terdapat keterkaitan dari bagian hulu dan hilir serta berbagai jenis sumber daya alam yang saling mempengaruhi. Daerah aliran sungai juga diartikan sebagai suatu wilayah daratan yang secara topografik dibatasi oleh punggung-punggung gunung yang menampung dan menyimpan air hujan untuk kemudian menyalurkannya ke laut melalui sungai utama (Asdak 2010). Daerah Aliran Sungai (DAS) di Indonesia memikul masalah yang kompleks, masalah-masalah tersebut diantaranya karena tekanan kepadatan penduduk yang sangat tinggi dan pemanfaatan sumber daya alam yang intensif yang mengakibatkan penurunan kondisi DAS seperti meningkatnya tanah longsor, erosi banjir, kekeringan serta sedimentasi, sehingga sebagian besar Daerah Aliran Sungai (DAS) Indonesia dapat dikatakan dalam keadaan kritis (Lestari \& Ridwan 2014).

Provinsi Riau memiliki 4 Daerah Aliran Sungai (DAS), yaitu DAS Rokan, DAS Siak, DAS Kampar dan DAS Indragiri yang mencakup Provinsi Riau dan Provinsi Sumatera Barat dengan 13 kabupaten/kota dan 117 kecamatan (Laporan Akhir Dewan Perwakilan Daerah Provinsi Riau 2014). Ekosistem wilayah Daerah Aliran Sungai di Provinsi Riau dibagi menjadi tiga bagian, daerah hulu, daerah tengah dan daerah hilir. Daerah hulu ini memiliki ciri-ciri daerah konservasi, kerapatan drainase yang lebih tinggi, kemiringan lereng yang besar lebih dari lima persen $(>5 \%)$, daerah hulu ini bukan daerah banjir. Daerah hulu sungai memiliki fungsi sebagai pengaturan serta penunjang tata air untuk daerah hilir. Daerah hilir memiliki ciri-ciri daerah pemanfaatan, daerah dengan kerapatan drainase lebih kecil, daerah hilir merupakan daerah dengan kemiringan lereng kecil sampai sangat kecil kurang dari delapan belah persen (18\%), namun di beberapa tempat tertentu merupakan daerah banjir yang menimbulkan genangan, dalam pengaturan pemakaian air ini sangat ditentukan oleh jenis tanaman pertanian disekitaran DAS dan bangunan irigasi, serta ditentukan oleh bakau dan hutan gambut terutama di daerah pantai dan estuaria.

Tanah gambut di daerah hilir berfungsi sebagai penahan masuknya air laut ke wilayah daratan, sebagai panampungan limpasan air dalam jumlah besar. Daerah tengah disebut sebagai daerah transisi antara daerah hulu dan hilir, daerah tengan mempunyai nilai-nilai ekosistem dan keanekaragamn hayati yang tinggi (Laporan Akhir Dewan Perwakilan Daerah Provinsi Riau 2014). Pengelolaan Daerah Aliran Sungai (DAS) yang dilakukan berdasarkan Peraturan Pemerintah RI Nomor 37 tahun 2012 tentang Pengelolaan Daerah Aliran Sungai, namun dalam pelaksanaannya kurang terimplementasi dengan baik, karena setiap DAS memiliki klarifikasi tersendiri yang berbeda dengan DAS-DAS lainnya. Klasifikasi dapat diartikan sebagai pengkategorian DAS berdasarkan kondisi lahan serta kualitas, kuantitas dan kontinuitas air, sosial ekonomi, investasi bangunan air dan pemanfaatan ruang wilayah (Peraturan Pemerintah Nomor 37 tahun 2012). Pengelolaan DAS Provinsi Riau diperlukan payung hukum yang khusus mengatur tentang DAS Provinsi Riau yang sesuai dengan klarifikasi dari DAS tersebut.

Pada tahun 2007 forum Daerah Aliran Sungai (DAS) Siak telah mengajukan draf tentang pengelolaan DAS Siak. Dalam hal ini Ketua Forum Daerah Aliran Sungai (DAS) Siak yaitu Prof. Adnan Kasry dipercaya menyusun draf Rancangan Peraturan Daerah Tentang DAS Siak. Dalam pelaksanaanya, draf pengelolaan DAS Siak tidak disahkan sampai sekarang, hal ini disebabkan oleh masalah sulitnya dalam memberikan nama dari lembaga tersebut. Permasalahan pemberian nama ini 
sangat terkait dengan kewajiban, kewenangan, serta tanggungjawab yang dimiliki oleh lembaga. Selanjutnya pada tahun 2014 draf tentang pengelolaan Daerah Aliran Sungai (DAS) diajukan sebagai Rancangan Peraturan Daerah Inisiatif dari Komisi B.

Pada tahapan proses kebijakan Peraturan Daerah tentang Pengelolaan DAS terdapat fenomena-fenomena permasalahan yang muncul pada tahapan formulasi kebijakan, permasalahan tersebut terdapat pada kurangnya perhatian instansi terkait terhadap hadirnya Raperda DAS inisiatif dari DPRD Provinsi ini, hal ini tercermin pada kurangnya partisipasi SKPD terkait dalam menghadiri hearing pembahasan Raperda yang dilaksanakan di DPRD Provinsi Riau. Perkembangannya dengan hadirnya Perda tentang pengelolaan Daerah Aliran sungai (DAS) di Provinsi Riau, sehingga dalam pengelolaan Daerah Aliran Sungai (DAS) berdasarkan pada Perda yang telah berlaku yaitu pada Peraturan Daerah No 9 Tahun 2014 tentang Pengelolaan Daerah Aliran Sungai. Berdasarkan paparan tersebut diatas, maka artikel ini ditujukan untuk memberikan analisis proses kebijakan perda tentang pengelolaan DAS, yang difokuskan pada tahap formulasi kebijakan.

\section{KAJIAN PUSTAKA}

Kajian tentang kebijakan tidak terlepas pada analisis kebijakan. Menurut Dunn dalam Krisna (2017) analisis kebijakan publik diartikan sebagai ilmu sosial terapan yang menggunakan berbagai metode penelitian dan argumentasi untuk menghasilkan informasi yang relevan dalam menganalisis masalah-masalah sosial yang mungkin timbul akibat diterapkannya suatu kebijakan. Analisis kebijakan menggunakan metode pengkajian multiple dalam konteks argumentasi dan debat politik untuk menciptakan secara kritis, menilai dan mengkomunikasikan pengetahuan yang relevan dengan kebijakan. Analisis kebijakan adalah aktivitas intelektual yang dilakukan dalam proses politik. Analisis kebijakan tidak dimaksudkan menggantikan politik dan membangun elite teknokratis. Analisis kebijakan diletakkan pada konteks sistem kebijakan (Nugroho 2009).

Menurut Dunn dalam Fransiska dkk (2013) terdapat tiga rangkaian kesatuan penting didalam analisis kebijakan publik yang perlu dipahami, yaitu formulasi kebijakan (policy formulation), implementasi kebijakan (policy implementation) dan evaluasi kebijakan (policy evaluation). Menurut Nugroho (2009), formulasi kebijakan adalah inti dari kebijakan publik karena disini dirumuskan batas-batas kebijakan itu sendiri. Membuat atau merumuskan kebijakan yang dikenal dengan formulasi kebijakan bukan suatu proses yang sederhana dan mudah, karena dalam hal ini terdapatnya faktor-faktor atau kekuatan-kekuatan yang dapat berpengaruh pada proses pembuatan kebijakan.

Studi mengenai formulasi kebijakan memberikan perhatian yang sangat dalam pada sifat-sifat perumusan permasalahan publik karena merupakan fundamen besar dalam merumuskan kebijakan publik sehingga arahnya menjadi benar, tepat dan sesuai. Perumusan masalah akan sangat membantu para analis kebijakan untuk menemukan asumsi-asumsi yang tersembunyi, mendiagnosis penyebagian-penyebagian masalah publik, memetakan tujuan-tujuan yang memungkinkan, memadukan pandangan yang berseberangan/bertentangan, dan merancang peluang kebijakan yang baru (Bintari \& Pandiangan 2016).

Menurut Jones dalam Muadi dkk (2016) secara umum aktor-aktor atau yang terlibat dalam proses formulasi kebijakan dibagi dalam dua kategori besar yakni; 1) 
aktor pemerintahan (inside government) yakni eksekutif, legislatif, yudikatif secara parsial, dan birokrasi. 2) aktor dari luar pemerintahan (outside government), yakni kelompok kepentingan (interest groups), akademisi, politisi, media massa, beneficiaries, dan lembaga-lembaga donor. Menurut Winarno (2014) dalam formulasi kebijakan terdapat beberapa tahapan, yaitu

1. Perumusan masalah (defining problem)

Dalam merumuskan masalah kebijakan dengan baik, yang perlu dilakukan pertama sekali yaitu mengenali dan mendefinikan masalah dengan baik.

2. Agenda kebijakan

Masuknya suatu masalah dalam agenda kebijakan harus memuat syaratsyarat, seperti apakah masalah tersebut mempunyai dampak yang besar bagi masyarakat dan membutuhkan penanganan yang harus segera dilakukan? Dalam agenda kebijakan masalah publik akan dibahas para perumus kebijakan, para perumus kebijakan seperti; legislatif (DPR), eksekutif (presiden dan para pembantunya), agen-agen pemerintah dan yudikatif.

3. Pemilihan alternatif kebijakan untuk memecahkan masalah

Para perumus kebijakan dalam memecahkan masalah publik dihadapkan pada kepentingan-kepentingan antara berbagai aktor-aktor yang terlibat dalam perumusan kebijakan.

4. Tahap penetapan kebijakan

Pemilihan alternatif kebijakan yang diambil pada dasarnya merupakan kompromi dari berbagai kelompok-kelompok kepentingan yang terlibat dalam pembentukan kebijakan. Tahap selanjutnya yaitu penetapan kebiujakan, penetapan kebijakan tersebut berupa undang-undang yurisprudensi, keputusan presiden, keputusan-keputusan menteri dan lain sebagainya.

Dalam kajian kebijakan pengelolaan Daerah Aliran Sungai terutama di Provinsi Riau, telah pernah dilakukan pada tahun 2014 yaitu tentang peran pemerintah daerah Provinsi Riau dalam pengelolaan Daerah Aliran Sungai Siak: studi kasus daerah hilir daerah aliran Sungai Siak tahun 2010-2013. Hasil penelitian menjelaskan bahwa peran pemerintah daerah Provinsi Riau dalam pengelolaan DAS Siak berdasarkan tugas pokok dan fungsi dari masing-masing instansi pemerintah daerah provinsi/kabupaten/kota terkait di wilayah DAS. Dalam pengelolaan DAS Siak dipengaruhi oleh faktor kekuasaan, kepentingan, dan strategi masing-masih instansi terkait pengelolaan DAS Siak. Pada dasarnya setiap instansi memiliki regulasi sendiri dan bekerja hanya berdasarkan tugas pokok dan fungsinya masing-masing, tidak adanya Peraturan Daerah Provinsi Riau yang khuhus dalam pengelolaan DAS Siak, sehingga dalam pengelolaannya tidak ada lembaga yang memiliki payung hukum yang kuat yang memiliki perhatian khusus dalam pengelolaan DAS Siak.

\section{METODE PENELITIAN}

Pendekatan yang digunakan dalam penelitian ini pendekatan kualitatif, dengan metode analisis deskriptif. Dalam menggunakan metode kualitatif penulis memiliki 
alasan yang didasarkan pada tujuan penelitian yaitu untuk menganalisis formulasi kebijakan Peraturan Daerah Provinsi Riau dalam pengelolaan Daerah Aliran Sungai, sehingga metode analisis deskriptif yang digunakan dapat memberikan gambaran bagaimana proses formulasi kebijakan Peraturan Daerah Provinsi Riau tentang Pengelolaan Daerah Aliran Sungai.

Pengumpulan data yang digunakam dalam penelitian ini yaitu menggunakan wawancara, observasi dan dokumentasi. Analisis data yang dilakukan dengan deskriptif yang diperoleh dari observasi secara langsung pada objek penelitian dan wawancara yang kemudian menghubungkannya secara kualitatif. Selanjutnya pengumpulan data diolah secara manual, direduksi. Hasil dari reduksi dikelompokkan dan kemudian disajikan dalam bentuk konten analisis dengan penjelasan-penjelasan. Terakhir akan diberikan kesimpulan.

\section{PEMBAHASAN}

Pembahasan dalam artikel ini didasarkan pada proses dari formulasi kebijakan yaitu, perumusan masalah (defining problem), agenda kebijakan, pemilihan alternatif kebijakan untuk memecahkan masalah, tahap penetapan kebijakan.

\section{Perumusan masalah (defining problem)}

Untuk merumuskan kebijakan, langkah awal yang perlu dilakukan yaitu mengenali, mendefinisikan, dan merumuskan masalah-masalah yang terdapat di DAS. Permasalahan DAS merupakan kesenjangan antar kondisi yang terjadi dengan kondisi yang seharusnya dalam suatu DAS yang meliputi aspek bio fisik, sosial, ekonomi, dan kelembagaan. Beberapa permasalahan yang menunjukkan adanya pencemaran dan perusakan di DAS Provinsi Riau baik yang berkaitan dengan DAS Indragiri, DAS Kampar, DAS Rokan, DAS Siak maupun sub-sub DAS-nya antara lain; meningkatnya jumlah penduduk dan industri yang melakukan aktivitas atau kegiatan usaha dengan mengahasilkan limbah di sepanjang DAS, berkurangnya tutupan hutan di DAS yang berfungsi sebagai daerah penyerap air karena alih fungsi hutan menjadi perkebunan, pertaniah, perladangan, dan pemukiman, meningkatnya lahan kritis, serta meningkatnya erosi dan sedimentasi DAS.

Secara spesifik dapat dijelaskan terkait permasalah-permasalahan yang terjadi di DAS Provinsi Riau diantaranya;

1. Aspek penurunan kualitas air; permasalahan timbul dalam pemenuhan kebutuhan air rumah tangga, kota dan industri (RKI) di beberapa wilayah DAS seperti DAS Siak dan DAS Kampar, kualitas airnya semakin tercemar sehingga tidak layak lagi menjadi sumber air baku PDAM. Pada DAS Siak kegiatan industri dan pemukiman menyumbang nilai $B O D=20,43 \mathrm{mg} / \mathrm{L}$ (baku mutu 2-3 mg/L) dan pengukuran COD = 47,30 mg/L (baku mutu 10-25 mg/L). Dari hasil tersebut dapat dikatakan bahwa Sungai Siak sudah mengalami pencemaran yang tinggi atau tercemar berat (Badan Lingkungan Hidup Provinsi Riau 2011)

2. Aspek banjir; potensi terjadinya banjir disebabkan oleh tingginya curah hujan di wilayah tengah, hulu dan di sepanjang DAS. Banjir dan genangan sering terjadi di daerah yang dilalui beberapa wilayah DAS. Pekanbaru menjadi daerah yang sering terkena dampak banjir Sungai Siak dan luas daerah 
rawan banjir di kota Pekanbaru mencapai 8.755 ha (Balai Wilayah Sungai Sumatera III, Tahun 2011).

3. Aspek lahan kritis; pembukaan hutan untuk fungsi lainnya yang beragam berlangsung secara berangsur-angsur dan tercatat seluas $\pm 2,04$ juta ha sampai dengan tahun 2009 (RT/RW Provinsi Riau, 2011). Pembukaan hutan yang terbesar yaitu peruntukan perkebunan sawit rata-rata pembukaannya mencapai 10.000 ha/tahunnya (Dinas kehutanan dan Perkebunan Provinsi Riau, 2011) .

4. Aspek kerusakan bantaran dan tebing sungai; kerusakan tebing disebabkan oleh faktor alam (abrasi dan longsor) dan hembasan gelombang dari lalu lintas kapal yang lewat, diantaranya Kabupaten Siak, Kota Pekanbaru dan Kabupaten Kampar.

5. Aspek sedimentasi sungai; data BP DAS Rokan Indragiri tahun 2010 nilai erosi DAS Siak mencapai \pm 200 ton/ha/tahun dengan tingkat sedimentasi sebesar \pm 400 juta ton/tahun (klasifikasi tingkat erosi berat).

6. Aspek konservasi sumber daya DAS

7. Aspek pemberdayaan sumber daya DAS

8. Aspek pengendalian daya rusak DASAspek sistem informasi DAS

9. Aspek pemberdayaan dan peningkatan peran masyarakat dan dunia usaha dalam usaha pengelolaan DAS

Selain itu berdasarkan hasil invetarisasi dan identifikasi produk hukum terkait pengelolaan DAS di Provinsi Riau belum memiliki produk hukum yang komprehensif dan integratif dalam pengelolaan DAS sehingga pencemaran dan perusakan DAS semakin meningkat baik secara kualitas maupun kuantitaf.

\section{Agenda Kebijakan}

Suatu masalah masuk menjadi agenda kebijakan apabila mendapat perhatian dari pembuat kebijakan. Dalam hal ini permasalahan DAS di Provinsi Riau yang begitu kompleks telah memperoleh perhatian yang luas dalam berbagai kalangan. Dalam proses agenda kebijakan dipilih berbagai masalah yang dinilai dampak yang besar terhadap masyarakat. Masalah publik tersebut akhirnya dibahas oleh perumus kebijakan yaitu DPRD Provinsi Riau dan dicari penyelesaiannya. Sebelumnya, pada perumusan masalah telah dijelaskan berbagai masalah yang terdapat di DAS Provinsi Riau, dan menjadi perhatian khusus untuk ditindaklanjuti. Empat permasalahan utama yang telah dijelaskan pada tahap perumusan masalah menjadi permasalahan prioritas yang masuk ke dalam agenda kebijakan.

Pada perencanaan pembentukan perda di DPRD diawali dengan pembuatan rancangan judul raperda tentang pengelolaan daerah aliran sungai secara tertulis oleh Komisi B yang disertai dengan analisa dasar regulasi meliputi: landasan hukum, kebutuhan yang telah didasarkan pada RPJMD dan RPJP Daerah Provinsi Riau, potensi beban dan manfaat, selanjutnya Komisi melakukan rapat internal dengan membahas judul raperda tentang pengelolaan daerah aliran sungai.

\section{Pemilihan Alternatif Kebijakan untuk Memecahkan Masalah}

Pemilihan alternatif dalam memecahkan masalah DAS di Provinsi Riau yaitu dengan membuat peraturan daerah di Provinsi Riau dalam pengelolaan DAS. Tujuan 
pembentukan peraturan daerah tentang Pengelolaan DAS ini yaitu sebagai pedoman dalam mengelola DAS di Provinsi Riau sebagai salah satu sumber utama kehidupan manusia dan satwa lainnya secara serasi dan seimbang melalui perencanaan, pelaksanaan, monitoring dan evaluasi serta pembinaan dan pengawasan. Tujuan pengelolaan DAS yang dilakukan oleh pemerintahan daerah Provinsi Riau bersama stakeholder bertujuan untuk;

1. Mewujudkan koordinasi, integrasi, sinkronisasi dan sinergi antar berbagai pihak dalam pengelolaan sumberdaya alam dan lingkungan DAS

2. Mewujudkan kondisi tata air di DAS yang optimal, meliputi jumlah, kualitas, dan distribusinya

3. Mewujudkan kondisi lahan yang produktif sesuai daya dukung dan daya tamping lingkungan DAS, dan

4. Mewujudkan kesejahteraan masyarakat.

\section{Tahap Penetapan Kebijakan}

Tahap penetapan kebijakan merupakan tahap akhir dalam pembuatan kebijakan, sehingga memiliki kekuatan hukum yang mengikat, yang merupakan hasil kompromi dan musyawarah dari berbagai kelompok-kelompok kepentingan yang terlibat dalam pembuatan keputusan. Sebelum penetapan kebijakan terdapat beberapa proses perumusan raperda tentang pengelolaan daerah aliran sungai yaitu;

1. Rapat Paripurna dalam rangka Penyampaian Raperda Inisiatif Komisi B DPRD Provinsi Riau tentang Pengelolaan Daerah Aliran Sungai Terpadu.

Pada rapat paripurna ini yang dipimpin oleh Noviwaldi Jusman dan dari Pemerintah Provinsi Riau dihadiri oleh Sekda Provinsi Riau Zaini Ismail pada penyampaian draf tentang Pengelolaan DAS Terpadu ini disambut baik, dengan harapan dapat menyelesaikan permasalahan-permasalan di DAS Riau, sehingga draf Raperda diserahkan kepada Ketua DPRD dan selanjutnya akan dilanjutkan dengan penyampaian pandangan fraksi pada paripurna berikutnya.

2. Penyampaian Pandangan Umum Fraksi tentang Ranperda Pengelolaan Daerah Aliran Sungai Terpadu Sekaligus Pembentukan Pansus.

Penyampaian Pandangan Umum Fraksi tentang Raperda Pengelolaan Daerah Aliran Sungai Terpadu dilakukan oleh Fraksi Partai Golkar, Fraksi Partai Demokrat, Fraksi PDI-P, Fraksi PAN, Fraksi PPP, Fraksi PKS, Fraksi Partai Gabungan. Selanjutnya naskah Pandangan Umum Raperda Pengelolaan Daerah Aliran Sungai Terpadu ini diserahkan kepada Komisi B. Penyampaian padangan umum fraksi sifatnya memberi masukan-masukan terhadap draf Raperda tentang Pengelolaan DAS Terpadu. Secara umum fraksi-fraksi meberikan apresisasi kepada Komisi B yang telah melahirkan usul inisiatif draf Pengelolaan DAS Terpadu. Masukan-masukan melalui pandangan fraksi ini diharapkan dapat memberikan masukan terhadap raperda. Melalui rapat paripurna dewan ini, DPRD Provinsi Riau selanjutnya membentuk panitia khusus pembahasan pengelolaan daerah sungai terpadu. 
3. Penyampaian jawaban panitia khusus terhadap pandangan umum fraksi tentang raperda inisiatif DPRD Provinsi Riau pengelolaan daerah aliran sungai terpadu.

Dalam rapat paripurna ini panitia pansus menyampaikan jawaban dari pandang dari fraksi-fraksi dari Fraksi Partai Golkar, Fraksi Partai Demokrat, Fraksi PDI-P, Fraksi PAN, Fraksi PPP, Fraksi PKS, dan Fraksi Partai Gabungan.

4. Penyampaian Jawaban Komisi B terhadap pandangan umum fraksi tentang Raperda Inisiatif Pengelolaan Daerah Aliran Sungai Terpadu sekaligus persetujuan untuk dijadikan raperda dan pembentukan pansus.

Pandangan yang telah disampaikan oleh fraksi-fraksi, selanjutnya akan menajdi pertimbangan dalam penyempurnaan Rancangan Peraturan Daerah tentang Pengelolaan DAS Terpadu, beberapa permasalahan yang dapat dihimpun dari fraksi-fraksi yaitu:

a) Sikronisasi Raperda dengan RPJM dan RPJP Provinsi Riau

b) Pemahaman mengenai Forum Koordinasi DAS Riau

c) Perlu dilakukan pengelolaan DAS secara Terpadu

d) Kendala dalam proses pembuatan Raperda tentang pengelolaan DAS Terpadu

e) Kepentingan-kepentingan stakeholder dalam Pengelolaan DAS

f) Permasalahan kewenangan dan tanggungjawab Pemerintah Daerah Provinsi dan Pemerintah Daerah Kabupaten/Kota dalam Pengelolaan DAS

g) Penjelasan tentang kedudukan dan ruang lingkup Raperda Pengelolaan DAS Terpadu

Berdasarkan rapat paripurna dewan, anggota dan pengurus panitia khusus pembahasan rancangan peraturan daerah pengelolaan daerah aliran sungai terpadu dapat menerima dan menyetujui susunan anggota dan pengurus panitia khusus pembahasan rancangan peraturan daerah pengelolaan daerah aliran sungai terpadu, sehingga dapat ditetapkan menjadi keputusan dewan.

5. Penyampaian Penjelasan Panitia Khusus Terhadap Raperda Inisiatif tentang Pengelolaan Daerah Aliran Sungai Terpadu.

Dalam kesempatan ini panitia khusus menyampaikanpenjelasan raperda mengenai pengelolaan DAS berdasarkan hasil pandangan dari fraksi-fraksi dan jawaban dari komisi B maupun dari Panitia khusus sendiri.

6. Penyampaian pendapat kepala daerah terhadap raperda inisiatif pengelolaan daerah aliran sungai terpadu.

Pemerintah Provinsi Riau menyampaikan apresiasi dan penghargaan yang tinggi kepada Dewan melalui Panitia Khusus yang telah membahas Raperda tentang Pengelolaan DAS, sehingga dapat meminimalisir permasalahan DAS yang ada. Raperda tentang pengelolaan DAS ini disusun sebagai pedoman mengelola DAS Provinsi secara seimbang melalui perencanaan, pelaksanaan, monitoring, dan evaluasi, serta pembinaan dan pengawasan. 
Melalui raperda tentang pengelolaan DAS diharapkan pihak-pihak terkait dapat membentuk sinergitas satu sama lain yang lebih besar.

7. Penyampaian jawaban fraksi terhadap pendapat kepala daerah tentang raperda inisiatif pengelolaan daerah aliran sungai terpadu

Tahap-tahapan dan mekanisme pembahasan suatu rancangan peraturan daerah yang diatur dalam tata tertib dewan, yakni Pasal 112 ayat (3), huruf a dan b; diantara tahap-tahap pembahasan suatu raperda adalah pandangan umum fraksi dewan dan jawaban fraksi terhadap pendapat kepala daerah. Selanjutnya setiap masing-masing fraksi akan menyampaikan pandangan umum dan jawaban fraksi terhadap pendapat kepala daerah, yang pertama yaitu dari Fraksi Golkar disampaikan oleh anggota dewan Musdar Mustafa, Fraksi Partai Demokrat disampaikan oleh Nasaruddin, Fraksi PDI-P disampaikan oleh Almainis, Fraksi PAN disampaikan oleh Ramli Sanur, Fraksi PPP disampaikan oleh Jabarullah, Fraksi PKS disampaikan oleh Mansyur HS, Fraksi Partai Gabungan atau Anggota disampaikan oleh Solihin.

8. Laporan Hasil Kerja Pansus terhadap Raperda Inisiatif tentang Pengelolaan Daerah Aliran Sungai Terpadu Sekaligus Persetujuan Dewan dan Pendapat Akhir Kepala Daerah.

Raperda inisiatif tentang pengelolaan daerah aliran sungai terpadu telah sampai pada tahap akhir, yakni laporan hasil kerja panitia khusus. Seluruh proses pembahasan raperda inisiatif dewan ini telah sesuai dengan mekanisme dan prosedur, sebagaimana yang diatur dalam tata tertib dewan Pasal 112. Dalam hal ini penyampaian laporan hasil kerja pansus disampaikan oleh Mansyur HS yang disampaikan dalam laporan hasil kerja pansus yaitu pendahuluan, dasar pembentukan pansus, landasar yuridis, mekanisme pambahasan, dan hasil pembahasan, dan penutup.

Dalam rapat paripurna disetujui laporan hasil kerja pansus rancangan peraturan daerah inisiatif tentang pengelolaan daerah aliran sungai terpadu di Provinsi Riau sehingga raperda tersebut dapat menjadi peraturan daerah. Yang disampaikan pada pandangan akhir yaitu; sesuai amanah UndangUndang No 12 Tahun 2011 tentang Pembentukan Peraturan Perundangundangan juncto Undang-undang No 23 Tahun 2014 tentang Pemerintah Daerah, maka Rancangan Peraturan Daerah yang telah disetujui bersama DPRD dan Gubernur akan ditetapkan sebagai Peraturan Daerah. Sebagaimana diatur dalam Pasal 78 Undang-undang Nomor 12 Tahun 2011, dalam jangka waktu paling lama 7 hari terhitung sejak tanggal persetujuan bersama. Rancangan Perda disampaikan oleh Pimpinan DPRD kepada Gubernur untuk ditetapkan menjadi Peraturan Daerah.

Berdasarkan analisis penulis, dari rapat-rapat paripurna yang telah dilakukan di Komisi B DPRD Provinsi Riau diantaranya; pandangan fraksi, penyampaian jawaban panitia khusus, penyampaian jawaban komisi, penyampaian penjelasan pansus, penyampaian pendapat kepala daerah, penyampaian jawaban fraksi terhadap raperda tentang pengelolaan das terpadu, secara umum draf awal raperda dengan draf setelah rapat paripurna yang telah dilakukan tidak mengalami perubahan yang signifikan, perubahan hanya berkisar pada penambahan konsep dalam pengelolaan DAS yang diwujudkan dalam raperda yaitu: 
1. Berkaitan pada Forum Koordinasi DAS dimuat pada BAB VIII forum koordinasi pengelolaan DAS pasal 49.

2. Konsep pengelolaan DAS terpadu dimuat dalam BAB IV pelaksanaan bagian kesatu umum pasal 20 dijelaskan kegiatan pengelolaan DAS.

3. Stakeholder pengelolaan DAS. Perlu dijelaskan kembali peran serta dan pemberdayaan.

4. Kewenangan dan tanggungjawab pemerintah provinsi dan kabupaten dimuat dalam BAB VII kewenangan dan tanggungjawab bagian kesatu pemerintah daerah provinsi pasal 47 dan bagian kedua pemerintah daerah kabupaten/kota pasal 48.

5. Kedudukan dan ruang lingkup raperda yang dimuat pada BAB II kedudukan dan ruang lingkup pasal 5.

\section{KESIMPULAN}

Raperda pengelolaan DAS di Provinsi Riau merupakan raperda inisiatif Komisi B DPRD Provinsi Riau, dalam proses perumusannya terdapat beberapa tahapan yang dilakukan. Analisis formulasi kebijakan peraturan daerah Provinsi Riau tentang pengelolaan DAS terdapat beberapa proses dan tahapan yaitu perumusan masalah (defining problem), agenda kebijakan, pemilihan alternatif kebijakan untuk memecahkan masalah, dan terakhir tahap penetapan kebijakan. Dalam tahapan ini dilakukan rapat paripurna di DPRD Provinsi Riau, yaitu diantaranya; pandangan fraksi, penyampaian jawaban panitia khusus, penyampaian jawaban komisi, penyampaian penjelasan pansus, penyampaian pendapat kepala daerah, penyampaian jawaban fraksi terhadap raperda tentang pengelolaan DAS terpadu. Proses perumusan raperda yang telah dilakukan secara umum draf awal raperda dengan draf setelah rapat paripurna yang telah dilakukan tidak mengalami perubahan yang signifikan, perubahan hanya berkisar pada penambahan konsep dalam pengelolaan DAS yang diwujudkan dalam raperda.

\section{DAFTAR PUSTAKA}

Asdak, Chay. (2010). Hidrologi dan Pengelolaan Daerah Aliran Sungai. Yogyakarta: Gadjah Mada University Press.

Bintari, Antik dan Landrikus Hartarto Sampe Pandiangan. (2016). Formulasi Kebijakan Pemerintah Tentang Pembentukan Badan Usaha Milik Daerah (BUMD) Perseroan Terbatas (PT) Mass Rapid Transit (MRT) Jakarta di Provinsi DKI Jakarta. Cosmogov 2(2): 113-129.

Fransiska, Muhammad Noor, dan Achmad Djumlani. (2013). Analisis Kebijakan Penanggulangan Kemiskinan Kabupaten Kutai Kartanegara. Jurnal Administrative Reform 1(3): 60-74.

Krisna, Fransisca Nur'aini. (2017). Policy Alternatives to Address Teacher Distribussion Inequality. Jurnal Analis Kebijakan 1(2): 45-58.

Laporan Akhir Dewan Perwakilan Daerah Provinsi Riau. (2014). Draft Rencana Peraturan Daerah Provinsi Riau tentang Pengelolaan Daerah Aliran Sungai Terpadu. 
Lestari, Reski dan Muhammad Ridwan. (2014). Peran Pemerintah Daerah Provinsi Riau dalam Pengelolaan Daerah Aliran Sungai Siak. Nakhoda: Jurnal IImu Pemerintahan 13(21): 21-38.

Muadi, Sholih, Ismail, dan Ahmad Sofwani. (2016). Konsep dan Kajian Teori Perumusan Kebijakan Publik. Jurnal Review Politik 6(2): 176-182.

Nugroho, Riant. (2009). Public Policy. Jakarta: PT Elex Media Komputindo.

Peraturan Pemerintah Nomor 37 tahun 2012 tentang Pengelolaan Daerah Aliran Sungai.

Winarno, Budi. (2014). Kebijakan Publik (Teori, Proses, dan Studi Kasus). Yogyakarta: Center of Academic Publishing Service. 